\title{
Last Time Seen
}

National Cancer Institute

\section{Source}

National Cancer Institute. Last Time Seen. NCI Thesaurus. Code C159693.

An indication of the most recent time that a particular event or status was noted. 